\title{
The risk factors for human cysticercosis in Mbulu District, Tanzania
}

\begin{abstract}
Authors:
Beda J. Mwang'onde ${ }^{1,2}$ Gamba Nkwengulila ${ }^{1}$ Mwita Chacha ${ }^{1,3}$

\section{Affiliations:}

${ }^{1}$ Department of Zoology and Wildlife Conservation, University of Dar es Salaam, Tanzania

${ }^{2}$ Division of Livestock and Human Diseases Vector Control, Tropical Pesticides Research Institute, Tanzania

${ }^{3}$ Wellcome Trust Fellow, Department of Zoology and Wildlife Conservation, Tanzania
\end{abstract}

Correspondence to: Beda Mwang'onde

Email:

bmwangonde@yahoo.ca

Postal address:

PO Box 35064, Dar es

Salaam, Tanzania

How to cite this article: Mwang'onde, B.J.,

Nkwengulila, G. \& Chacha, M., 2014, 'The risk factors for human cysticercosis in Mbulu District, Tanzania', Onderstepoort Journal of Veterinary Research 81(2), Art. \#719, 5 pages. http:// dx.doi.org/10.4102/ojvr. v81i2.719

\section{Note:}

Proceedings of the 2 nd One Health Conference in Africa. Jointly organised by the Southern African Centre for Infectious Disease Surveillance and the Tanzania National Institute for Medical Research, held at the Snow Crest Hotel in Arusha, Tanzania from 16th to 19th April 2013: http://www. sacids.org/kms/frontend/ index.php? $\mathrm{m}=119$.

\section{Read online:}

Scan this $Q R$ code with your smart phone or mobile device to read online.
The objective of this study was to explore the reasons for the persistence of human cysticercosis (HCC) transmission in Mbulu District, northern Tanzania. The study was carried out in 25 villages, whereby five major risks were identified. The risks were indiscriminate defaecation and improper use of toilets; a free-range system of keeping pigs; indiscriminate or unregulated slaughtering and inadequate meat hygiene and inspection; consumption of undercooked and porcine cysticerci infected pork; and social structure and roles. All of the identified risks were backed up by the immanent lifestyles of the community involved. These findings are important for the development of intervention strategies in the study area.

\section{Introduction}

Human cysticercosis (HCC) is a tissue invasion by the pork tapeworm larvae, Taenia solium. Humans are definitive hosts of T. solium and are infected by eating undercooked pork that contains viable cysticerci. The cysticercus develops into an adult tapeworm in the gut which produces large numbers of eggs which pass out in the faeces. The disease is among the neglected tropical diseases (NTDs) with a negative impact on public health and the piggery industry. It is endemic in most resource poor countries where sanitation is inadequate and free-range pig farming is practiced (Garcia et al. 2003). However, as a result of migrations, tourism and globalisation, HCC is also reported in industrialised countries (Canas et al. 2005; Schantz et al. 1998) where sanitation is adequate. Also, there have been case reports of HCC among communities of Muslims (Shandera \& Kassy 2006) and Orthodox Jews (Schantz et al. 1998; Moore et al. 1995). The features for a global epidemiology of HCC include frequent travel to endemic areas, residence and/or household contact (Del Brutto 2012). Therefore, with globalisation and increased tourism, the disease poses a threat worldwide.

The prevalence of HCC in Mbulu District is 16.3\% (Mwang'onde et al. 2012) and that of porcine cysticercosis (PCC) is $17.4 \%$ (Ngowi et al. 2004a). A computed tomography (CT) scan of HCC sero-positive patients based on cysticercosis WB IgG (immunoblot assay test) from the 25 villages of study showed that over $76.0 \%$ had lesions suggestive of human neurocysticercosis (NCC). Furthermore, hospital-based studies on people with epilepsy (PWE) reported a prevalence of NCC of over $14.0 \%$ (Winkler et al. 2008; Willingham et al. 2008). Nevertheless, most studies in Tanzania have focused on the prevalence of PCC (Phiri et al. 2003; Ngowi et al. 2004b; Boa et al. 2006; Mkupasi et al. 2010); risk factors for PCC (Ngowi et al. 2004a); and the control of PCC and its financial implications (Ngowi et al. 2007). According to Mwang'onde et al. (2012), Winkler et al. (2008) and Willingham et al. (2008), the prevalence of HCC in Mbulu District is worrying. The risks associated with the high prevalence of HCC in the district have never been documented. The present study, therefore, documents the risk factors associated with the persistence of HCC in Mbulu District, northern Tanzania.

\section{Materials and methods}

\section{Study area and ethical clearance}

The study was carried out in Mbulu District $\left(3^{\circ} 48^{\prime}-4^{\circ} 30^{\prime} \mathrm{S}, 35-36^{\circ} \mathrm{E}\right)$ from September 2011 to April 2013. Mbulu District has a population of 320279 (NBS 2012). The area lies at an estimated altitude of $1000 \mathrm{~m}-2400 \mathrm{~m}$ above sea level. The climate ranges from semi-arid to sub-humid, with an annual rainfall of $<400 \mathrm{~mm}$ and $>1200 \mathrm{~mm}$, respectively. There are two rainy seasons with two peaks of maximum rains. The long rainy season extends from about March to mid-May and the short rainy period from November to December. In between (January through February) is a dry spell and the dry season is between June and October. The relative humidity ranges from $55 \%$ to $75 \%$ and the mean annual temperature ranges from $15{ }^{\circ} \mathrm{C}$ to $24{ }^{\circ} \mathrm{C}$. Ethical clearance for the study was granted by the National Institute for Medical Research (NIMR), NIMR/HQ/R.8a/Vol. IX/1297.

Copyright: () 2014. The Authors. Licensee: AOSIS OpenJournals. This work is licensed under the Creative Commons Attribution License. 


\section{Data collection}

Information on sanitation, hygiene, systems of pig raising, knowledge of PCC and HCC, meat eating behaviour, age and gender roles, animal-human interactions and, community's attitude towards PCC was sought from 80 HCC sero-positives and the general community. An administered questionnaire, face-to-face interviews via field-farmer meetings, radio session dialogues, archives reviews and field observations were the techniques used to obtain information (Figure 1). Traditional customs regarding the above parameters were also teased out. The study was cross-sectional, thus there were no demarcations or classifications between cases and controls among interviewees which would reduce bias in the identification and estimation of exposure to risk factors.

\section{Statistical analysis}

Data entry and validation was carried out using MS-Excel 2010 version (MS Corp., Redmond, WA, USA). Risk factors were analysed using the Statistical Package for Social Sciences version 19.0 (SPSS Statistic 19, 2010 IBM). A logistic regression (odds ratio [OR]) (Szumilas 2010) analysis was used to measure the association between various identified exposure risks for HCC (confidence interval [CI] = 95\%).

\section{Results \\ Demographic characteristics}

Mbulu District has a population of 320279 (0.98:1 female/ male ratio) (NBS 2012). The population is skewed to the left as a large proportion (76.3\%) of the population is aged 0-29 years, with 4-14-year-olds counting the highest number $(50.6 \%)$ followed by the 15-29-year-olds (25.7\%). Males predominate in most age groups except in the 30-44 and 60-79 age groups (Table 1).

\section{Characterisation of risk factors for human cysticercosis}

The Mbulu community was historically pastoralist but currently practice mixed farming. Members of this community, particularly men, have a high preference for eating bloody or undercooked meat $(p=0.00049)$. The population of Mbulu community is dominated by males (NBS 2012). The age groups from 13-60 are among the highly active who commonly attend local clubs $(p=0.0019)$ where meat consumption goes together with alcohol intake. In this community, pork is the most consumed meat in local brew clubs $(p=0.0475)$, followed by beef $(p=0.1675)$, mutton $(p=0.284)$ and poultry $(p=0.921)$. Although every household owns a toilet, these either lack frequent visits by household members or are very small for an adult to comfortably utilise. These small and unappealing toilets are located in front of almost every household purposefully to escape penalties from health authorities for not having them. Nevertheless, about $12.9 \%(n=31)$ of heads of households amicably expressed their preference for not sharing a latrine with their daughters. This belief provides room for people to relieve themselves in bushes and elsewhere where roaming pigs can easily access human faeces. Furthermore, the toilets in some households are located very far from the house and have a very small hole which entertains defaecation around the brims which attracts the attention of roaming pigs. It is also acceptable by an appreciable proportion of the population that indiscriminately disposed children's stool serves a
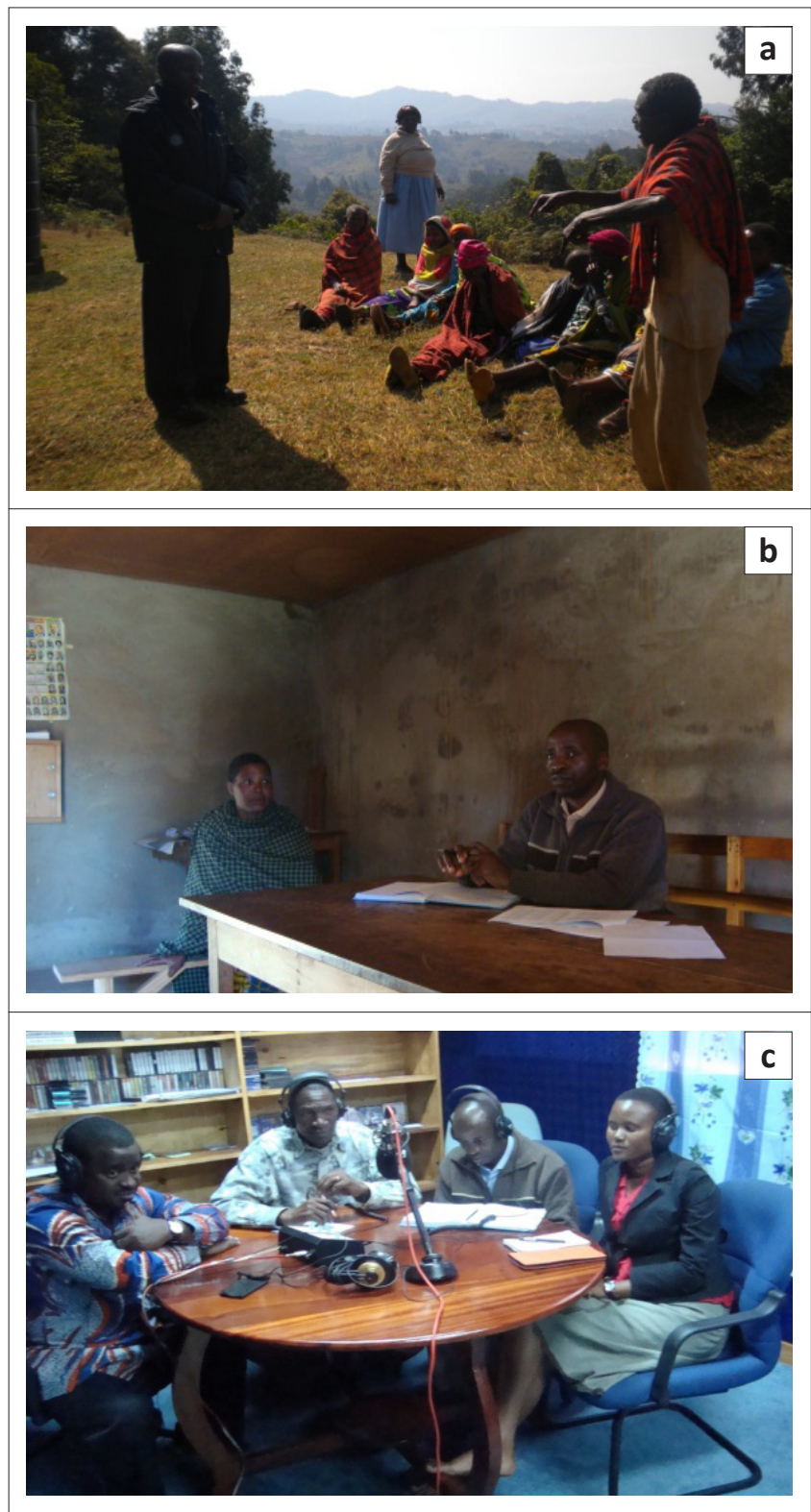

Source: Photos by Chacha Mwita, UDSM

FIGURE 1: Techniques used to collect information on HCC risks, (a) Field meetings; (b) Interview session and (c) Dialogue with community members through their local radio.

TABLE 1: Population structure of Mbulu District.

\begin{tabular}{lccc}
\hline Age & \multicolumn{2}{c}{ Population by sex } & \multirow{2}{*}{ Total } \\
\cline { 2 - 3 } & Males & Females & \\
\hline $0-4$ & 33244 & 31789 & 65033 \\
$5-14$ & 49241 & 47872 & 97113 \\
$15-29$ & 41418 & 40792 & 82210 \\
$30-44$ & 23349 & 24699 & 48048 \\
$45-59$ & 11816 & 10836 & 22652 \\
$60-69$ & 3531 & 3928 & 7459 \\
$70-79$ & 2214 & 2364 & 4578 \\
$80+$ & 2719 & 1437 & 1282 \\
\hline
\end{tabular}


purpose as a source of food for farmyard animals like pigs, dogs and chickens. In addition, over $2 / 3$ of the latrines in these communities are easily accessed by scavenging pigs.

There were no official slaughter slabs in the study area, consequently, and to avoid inconvenience the seller's house (homestead) becomes the slaughter place at that particular time of business (Figure 2). The official meat inspector, if available, inspects pork carcasses at homesteads. Water wells down the hill are the reliable source of domestic water $(p=$ $0.00048)$ with a minority of the population $(p=0.0192)$ having access to running water.

Indiscriminate defaecation and improper use of toilets $(\mathrm{OR}=3.0 ; 95 \% \mathrm{CI}, 1.028-8.755)$; a free-range system of keeping pigs (OR $=5.0 ; 95 \% \mathrm{CI}, 1.195-20.922)$; indiscriminate or unregulated slaughtering, inadequate meat hygiene and inspection (OR $=6.5 ; 95 \% \mathrm{CI}, 2.009-21.033)$; consumption of undercooked and infected pork (OR = 1.25; 95\% CI, 0.681-2.293); and social structures and roles $(\mathrm{OR}=0.75$; $95 \% \mathrm{CI}, 0.382-1.471$ ) were found to be the five main risk factors for HCC epidemiology in Mbulu.

\section{Discussion}

The present study documents for the first time the reasons for the persistence of HCC in Mbulu District. Various risk factors were identified; however, the discussion is mainly on the five risks identified as most potential for the epidemiology of taeniosis-cysticercosis or HCC in Mbulu.
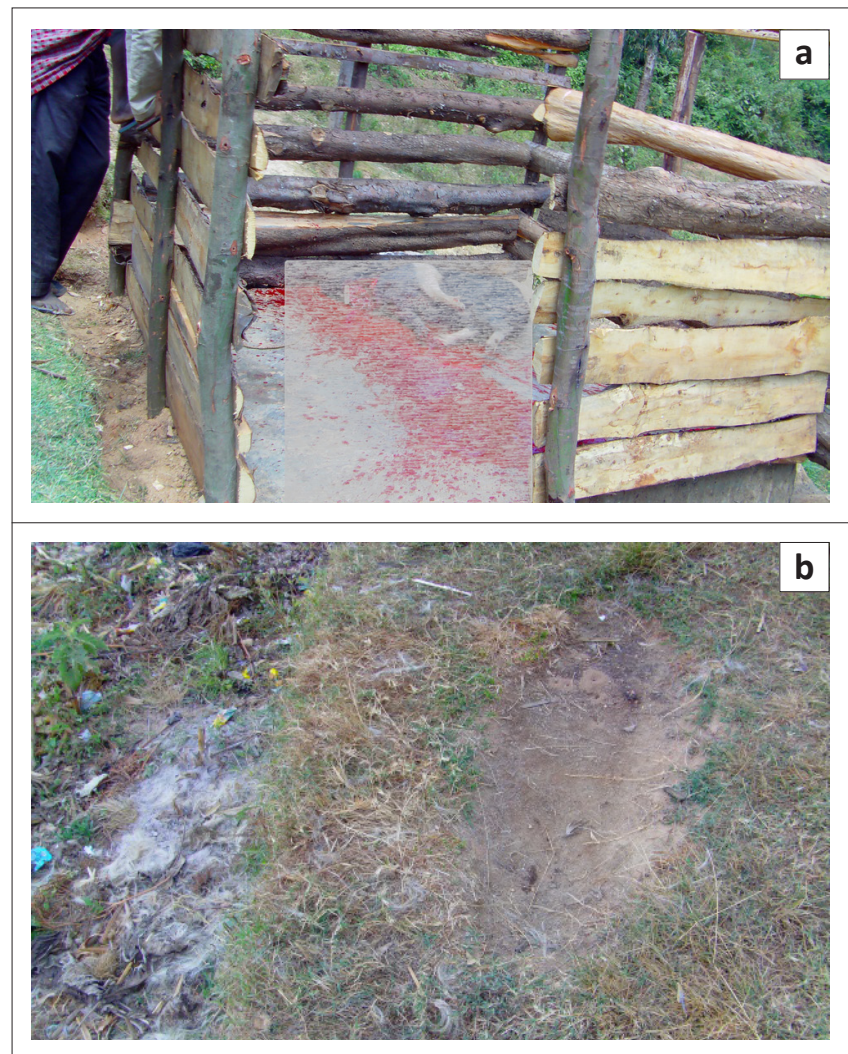

Source: Photos by Chacha Mwita, UDSM

FIGURE 2: The Mbulu District, (a) an individually owned slaughtering pen at a pork seller's house and (b) a slaughtering place near a local brew club.

\section{Indiscriminate defaecation and improper use of toilets}

This is a practice where people in a community do not utilise the available toilet facilities but rather go to relieve themselves in the open, among bushes. The practice pollutes ground waters, contaminates agricultural produce and helps the spread of viral, bacterial and parasitic diseases. The practice is detrimental to human and animal health and to social economic development, as among others it poses a high risk of cysticercosis in areas where pigs are kept as it facilitates the lifecycle of T. solium.

The reasons for indiscriminate defaecation and improper use of toilets in Mbulu District include the belief that human faeces are a good and readily available source of food for domestic animals, therefore children should relieve themselves in play grounds which roaming pigs, scavenging chickens and pet dogs can easily access. Some would like to examine their stool soon after excretion searching for any abnormalities of the gastrointestinal tract (GIT); others would not like to share a toilet hole with their daughters; and others believe that the process of constructing pit latrines or toilets brings misfortunes among members of the clan; hence defaecation in the bushes is a comfortable and safe practice. Considering all these reasons advanced by different households and/or clans, it is reasonable to suggest that these communities, in general, prefer relieving themselves in bushes rather than in toilets.

\section{Free-range system of raising pigs}

About $96 \%$ of the pigs in Mbulu District are kept under a freerange system (Ngowi et al. 2004a). This system of keeping pigs in Mbulu goes back to ancestral times when pigs were grazed with large and small ruminants in grazing lands; in some communities it is still practiced. They believe the system to be economical in terms of feeds, pens construction and time management. However, elsewhere, Vaga (2009) reports the system to be less productive in terms of weight gain per unit of food consumed. Raising and allowing pigs to feed on human faeces risks human and porcine cysticercosis (Cao et al., 1997; Allan et al. 2005). The 25 villages involved in the present study permit pigs to scavenge around the bush and pigsties. Such feeding methods not only raises the risk of PCC, but also increases the public health risk of HCC in the community.

\section{Consumption of undercooked infected pork}

The Manyara region's ethnic communities include the Iraqw, Mbugwe, Hadzabe, Fyomi, Maasai, Barabaig, Nyisanzu and Alawa in which, with the exception of the Hadzabe who are mostly hunter-gatherers, these ethnic groups share some common values as they are pastoralists by nature. People from these communities prefer grilled or smoked meat to other cooking methods. Heavy drinking, particularly by the men in the community, inevitably leads to the consumption of undercooked meat at local social clubs, and the practice perpetuates the Taenia spp. life cycle, among other parasitic life, which is a potential health risk for HCC. 


\section{Improper and lack of meat hygiene and inspection}

In Mbulu District, authorised personnel (i.e. para-vets) have often been directing slaughter or butcher men to make cuts in pork carcasses in their absence based on what they used to see from experts or professionals during routine meat inspection. Furthermore, the whole district of Mbulu has no single legal collective slaughter slab for pigs other than open slaughter places. Most pigs are slaughtered without ante mortem inspection, which is a prerequisite procedure, and then a para-vet is consulted for the inspection process. In the case where a carcass is infected with cysticerci, a para-vet would never be consulted and the carcass is set for a barter trade or sold at over $50 \%$ less of normal value. This situation allows cysticerci infected pork to enter the markets, thus perpetuating taeniosis in the area.

Proper meat hygiene and inspection is essential for public health because zoonosis account for $60 \%$ of all infectious disease pathogens and $75 \%$ of all emerging pathogens (Komba et al. 2012). Therefore, all animals intended for slaughter should be inspected while live, and post slaughter by authorised personnel to make sure meat for human consumption is not only fit and wholesome but also free from zoonosis (TFDA 2003). The Tanzania Food, Drugs and Cosmetics Authority (TFDA) further stipulates that premises for slaughtering animals intended for supply, sell, offer or expose for sale of meat for human consumption shall be registered by the Authority, which is not the case in Mbulu. Among others, the TFDA Act No. 1, 2003 prescribes the methods, instruments or appliances which may be used to carry out slaughtering; monitor and manage the slaughter and butchery facilities for suitability; marking or labeling of carcasses and viscera; and treatment and disposal of any animal, carcass or viscera, or any part of them for the intended purpose. Yet, in Mbulu whenever an authorized person rules for the total condemnation of a carcass or part of it, if not bunt to ash or disposed to a level that cannot be easily accessed, it is scavenged and consumed by the community.

\section{Social structure and gender}

Gender is the relationship between men and women, both perceptual and material and it is a central organising principle of societies, and often governs the processes of production and reproduction, consumption and distribution (FAO 1997). Based on a general community study on the sero-prevalence of human cysticercosis in Mbulu District by Mwang'onde et al. (2012), the frequency was higher in males than females. Furthermore, the sero-positivity ratio of HCC between females and males was 1:3 $(n=171)$ from the participation ratio of $1: 1.7(n=1051)$. This signifies that regardless of the high population of males (NBS 2012) and the recruitment ratio, males were more frequently infected with cysticerci than females. In this community, women are not allowed to participate in an economic or social activity unless they get the permission of their husbands and this might be the main reason for the low proportion of women participating in this study. Furthermore, men's freedom to attend social functions exposes them to a greater risk of infection with $T$. solium cysticercosis.

According to Flintan (2011), men and women have different abilities to access different opportunities in most developing countries, particularly in agro-pastoral communities. These differences also limit women's integration in the market economy, allowing men to dominate the marketing of farm products. Agro-pastoral societies are patrilineal and maledominated with strongly marked gender roles, a pattern which is extremely similar across the world, hence men are responsible for managing and selling meat animals (FAO n.d.). This situation also exists in Mbulu District, where males dominate livestock production and marketing. At their livestock markets, famously known as 'mnada', there is massive consumption of alcoholic drinks and freshly slaughtered meat, including pork, barbecued over open fires.

\section{Conclusion}

Populations accustomed to open or indiscriminate defaecation may require a substantial change in cultural values and behaviour through education towards using fixed-point facilities. Without such change, people may not use latrines at all or may use them in a way that undermines the potential health benefits. It is important to understand what stimulates people's interest in hygiene and sanitation. Health is one factor, but convenience, dignity, and social status may provide a stronger motivation. Once behaviours are recognised by a community, there is a pressure to conform, and social structures and leaders begin to contribute to the adoption of new behaviour. Therefore, to change attitudes towards hygiene and eating behaviour, education programmes should be the central focus, not only in Mbulu but also in areas with similar settings.

\section{Recommendations}

The principal advantage of the findings of this study on cysticercosis persistency in Mbulu paves the way for planning community-based control interventions. Thus, the information obtained serves in developing an appropriate strategy for breaking the cycle and therefore control of T. solium cysticercosis in Mbulu. Since the current study focused on the HCC prevalence based on the general community's sero-screening, further investigation is needed to examine outpatients and inpatients and environmental contamination by $T$. solium eggs to evaluate how big the risk of HCC is, in order to enhance the development of the best approach to controlling the disease in Mbulu District.

\section{Acknowledgements}

The authors wish to thank Mr. Amoniche Mtweve from Mbulu District Council for his invaluable organisational support during field work; we further thank the Mbulu District officials for their amicable acceptance of this study in their district. 
The research for this article was carried out within the framework of the consortium Afrique One 'Ecosystem and Population Health: Expanding Frontiers in Health'. Afrique One is funded by the Wellcome Trust (WT- 087535MA) and the University of Dar es Salaam hosted and facilitated the project.

\section{Competing interests}

The authors declare that they have no competing interests in the writing of this article.

\section{Authors' contributions}

M.C. (University of Dar es Salaam and Wellcome Trust) designed the study. B.J.M. (University of Dar es Salaam and Tropical Pesticides Research Institute), M.C. and G.N. (University of Dar es Salaam) carried out field work. B.J.M. drafted the manuscript and carried out data analysis and results interpretation. G.N. and M.C. revised the manuscript. The final version of the manuscript was approved by all authors.

\section{References}

Allan, J.C., Avila., G., Brandt, J., Correa D., Del Brutto, O.H., Dorny, P., Flisser A., Garcia, H.H., Ito, A., Kyvsgaard, N.C., Maravilla, P., McManus, D.P., Meinardi, H. \& Murrell, K.D., 2005, WHO/FAO/OIE Guidelines for the surveillance, prevention and contro of taeniosis/cysticercosis, viewed 23 November 2012, from http://www.oie.int

Boa, M.E., Mahundi, E.A., Kassuku, A.A., Willingham, A.L. \& Kyvsgaard, N.C., 2006, 'Epidemiological survey of swine cysticercosis using ante-mortem and postmortem examination tests in the southern highlands of Tanzania', Veterinary Parasitology 139(1-3), 249-255. http://dx.doi.org/10.1016/j.vetpar.2006.02.012

Canas, N.M., Calado, S.L. \& Vale, J., 2005, 'Treatment of racemose neurocysticercosis of the spine', Revue Neurologique 40, 544-547.

Cao, W., Van der Ploeg, C.P.B., Xu, J., Gao, C., Ge, L. \& Habbema, J.D.F., 1997, 'Risk factors for human cysticercosis morbidity: a population-based case-control
study', Epidemiology and Infection 119, 231-235. http://dx.doi.org/10.1017/ study', Epidemiology
S0950268897007619

Del Brutto, O.H., 2012, 'Neurocysticercosis in a 2-year-old boy infected at home', Pathogens and Global Health, 106(2)

FAO., 1997, Gender: The key to sustainability and food security, viewed 06 January 2013, from http://www.fao.org/docrep/007/

FAO, n.d., Social and cultural institutions of pastoralism: Pastoralism in the new millennium, Agriculture and Consumer Protection', viewed 06 January 2013, from http://www.fao.org/docrep/005/

Flintan, F., 2011, Changing nature of gender roles in the dry lands of the horn and East Africa: Implications for DRR programming. Regional Learning and Advocacy Project for vulnerable dry land communities, viewed 13 December 2012 from http://www.disasterriskreduction.net/east-central-africa/reglap
Garcia, H.H., Gilman, R.H., Gonzalez, A.E., Verastegui, M., Rodriguez, S., Gavidia, C., Tsang, V.C., Falcon, N., Lescano, A.G., Moulton, L.H., Bernal, T. \& Tovar, M., 2003, 'Cysticercosis Working Group in Perú. Hyperendemic human and porcine Taenia solium infection in Perú', American Journal of Tropical Medicine and Hygiene 68(3), 268-75.

Komba, E.V.G., Komba, E.V., Mkupasi, E.M., Mbyuzi, A.O., Mshamu, S., Luwumba, D., Busagwe, Z. \& Mzula, A., 2012, 'Sanitary practices and occurrence of zoonotic conditions in cattle at slaughter in Morogoro Municipality, Tanzania: Implications for public health', Tanzania Journal of Health Research 14(2). http://dx.doi. org/10.4314/thrb.v14i2.6

Mkupasi, E.M., Ngowi, H.A. \& Nonga, H.E., 2010, 'Prevalence of extra-intestinal porcine helminth infections and assessment of sanitary conditions of pig slaughter slabs in Dar es Salaam city, Tanzania', Tropical Animal Health and Production 43, 417-423. http://dx.doi.org/10.1007/s11250-010-9708-x

Moore, A.C., Larry, I.L., Schantz, P., Pilcher, J.B., Marianna, W., Allen, W.H., Edward, K.C., Elfatih, I.M.A. \& Joyce, R.G., 1995, 'Seroprevalence of cysticercosis in an Orthodox Jewish community', American Journal of Tropical Medicine and Hygiene 53(5), 439-442.

Mwang'onde, B.J., Nkwengulila, G. \& Chacha, M., 2012, 'The Serological Survey for Human Cysticercosis Prevalence in Mbulu District, Tanzania', Advances in Infectious Diseases 2(3), 62-66. http://www.SciRP.org/journal/aid

NBS, 2012, Tanzania Population and Housing Census, viewed 23 February 2013, from http://www.nbs.go.tz/sensa/popu2.php

Ngowi, H.A., Kassuku, A.A., Maeda, G.E.M., Boa, M.E., Carabin, H. \& Willingham, A.L., 2004a, 'Risk factors for the prevalence of porcine cysticercosis in Mbulu District, Tanzania', Veterinary Parasitology 120, 275-283. http://dx.doi.org/10.1016/j. vetpar.2004.01.015

Ngowi, H.A., Phiri, I.K., Afonso, S., Matenga, E., Boa, M.E., Mukaratirwa, S., Githigia, S., Saimo, M., Sikasunge, C., Maingi, N., Lubega, G.W., Kassuku, A., Michael, L., Siziya, S., Krecek, R.C., Noormahomed, E., Vilhena, M., Nsengiyumva, G., Andriantsimahavandy, A., Dorny, P., Johansen, M.V. \& Willingham, A.L., 2004b, 'Taenia solium cysticercosis in eastern and southern Africa: An emerging problem 'Taenia solium cysticercosis in eastern and southern Africa: An emerging problem Public Health 35 (1), 266-270.

Ngowi, H.A., Mlangwa, J.E.D., Carabin, H., Mlozi, M.R.S., Kassuku, A.A., Kimera, S.I. \& Willingham, A.L, 2007, 'Financial efficiency of health and pig management education intervention in controlling porcine cysticercosis in Mbulu District northern Tanzania', Livestock Research for Rural Development 19(62), viewed 17 August 2011, from http://www.Irrd.org/

Phiri, I.K., Ngowi, H., Afonso, S., Matenga, E., Boa, M., Mukaratirwa, S., Githigia, S., Saimo, M., Sikasunge, C., Maingi, N., Lubega, G.W., Kassuku, A., Michael, L., Siziya, S., Krecek, R.C., Noormahomed, E., Vilhena, M., Dorny, P. \& Willingham, A.L., 2003 'The emergence of Taenia solium cysticercosis in Eastern and Southern Africa as a serious agricultural problem and public health risk', Acta Tropica 87, 13-23. http:// dx.doi.org/10.1016/S0001-706X(03)00051-2

Schantz, P.M., Wilkins, P.P. \& Tsang, V.C.W., 1998. 'Immigrants, imaging, and immunoblots: The emergence of neurocysticercosis as a significant public health problem', in W.M. Shield, W.A. Craig, J.M Hughes (eds.), Emerging Infections, vol. 2 pp. 213-242, ASM Press, Washington, DC.

Shandera, W.X. \& Kassy, J.S., 2006, 'Neurocysticercosis: Current knowledge and advances', Current Neurology and Neuroscience Reports 6(6), 453-459. http:// dx.doi.org/10.1007/s11910-006-0046-3

Szumilas, M., 2010, 'Explaining odds ratios', Journal of the Canadian Academy of Child and Adolescent Psychiatry 19(3), 227-229. PMC2938757

TFDA, 2003, The Tanzania Food, Drugs and Cosmetics Act No. 1, 2003. The Government Printer, Dar es Salaam,Tanzania, viewed 11 Februery 2013, from http://www.tfda. or.tz/index/view/acts/

Vaga, M., 2009, Keeping pigs in a free range system, Estonian University of Life Sciences, viewed 21 December 2012, from http://oe.confolio.org/

Willingham, A.L., Harrison, L.J., Fèvre, E.M. \& Parkhouse, M.E., 2008, 'Inaugural meeting of the Cysticercosis Working Group in Europe', Emerging Infectious Diseases 14(12), e2. $h$ ttp://dx.doi.org/10.3201/1412.080889

Winkler, A.S., Blocher, J., Auerd, H., Gotwalde, T., Matuja, W. \& Schmutzhard, E., 2008, 'Anticysticercal and antitoxocaral antibodies in people with epilepsy in rural Tanzania', Transactions of the Royal Society of Tropical Medicine and Hygiene 102, 1032-1038. http://dx.doi.org/10.1016/j.trstmh.2008.05.004 